\title{
The Engineering of Non-Electrical Wheat Cracker Dough Cutting Tool
}

\author{
Sulharman, Jantri Sirait, and Wara W.E. Saptaningtyas
}

\begin{abstract}
The cracker cutter has been developed for many years, but still expensive, less effective, and not suitable for wheat cracker cutting. The purposes of this research is to design a tool for suitable cutting, cheap and non-electrical wheat crackers. The design apply using stainless wire and mechanism of the suppressor for cutting. To be able to engineer the tools, it is necessary to prepare materials such as iron elbow, stainless steel, iron plates, bolts, stainless wires, pipes polyvinyl chloride (pvc) and springs. The results show that an average cutting timez about $12 \mathrm{~kg} / \mathrm{hour}$. In economic calculation there is discrepancies capacity per month $2060 \mathrm{~kg}$ or IDR. 123,600,000. There is an increase in capacity of $1700 \%$.
\end{abstract}

Keywords — cutting tools, wheat crackers, non-electrical.

\section{INTRODUCTION ${ }^{1}$}

$\mathrm{C}$ rackers is known as a snack and complementary side dish. Though at the moment, there are lot of food snacks but the crackers are able to attract the hearts of the people. This statement proves that Small Medium Enterprise (SME) makes the crackers become one of business opportunities for the community. Since it is a home industry, it is needed a piece of equipment that can maximize the result of the production. Types of crackers varies ranging from prawn crackers, vegetable crackers, onion crackers, fish crackers, tempe crackers, etc. However, in the manufacturing process, it is still using manual way (cut by hand) and it is done in their home.

In Kota Bangun city, Kutai Kartanegara (Kukar), crackers industries use raw material such as; wheat flour, meat, fish and other herbs. One of them is Ananda Kiki whom produce wheat crackers. The process of production of wheat crackers is milling the raw material, adding some seasonings then putting the mold into one with diameter $9 \mathrm{~cm}$, length $16 \mathrm{~cm}$, then coming to the process of boiling for 1 hour 30 minutes, then carrying out to cutting process. The cutting process of wheat crackers are still using a very simple way and manual that is by using kitchen knife as shown in Figure 1 [1].

In terms of efficiency and productivity, it is still quite low and requires a lot of energy and quite a long time. So that the process of cutting wheat crackers does not require a lot of energy and a long time, it is necessary to engineer a wheat cracker tool.

Several cutting tools that can be found in market are the tool that developed by CV. Sumber Makmur Mekanik. This tool is used for cutting/slicing the cracker bar automatically. This tool uses two motorcycles. Once operates can be a few pieces of dough crackers. These devices are sold with price range of 15-20 million rupiah pe unit [2]. Shown in Figure 3. Because of the price per unit is quite expensive, many crackers small industries are not able to buy it [personal information].

Crackers cutting tool by Rapian Nur.This cut is similar to the same tool with the draft CV. Sumber Makmur Mekanik just dough that can be cut to just one

Sulharman, Jantri Sirait AND Wara W.E. Saptaningtyas are researcher with Institute for Research and Standardization of Industry of Samarinda, Ministry of Industry of the Republic of Indonesia, 75124, Indonesia. E-mail: sulharman@kemenperin.go.id
[3]. There are still pieces of flawed results, not round intact. Shown in Figure 4.

Other cracker cutting tools are homemade crackers cutting tool by Ahmad consists of a blade placed on the lever manually-driven discounter. Shown in Figure 5. The weakness of the tool is that it cannot be used to cut the supple dough, so that it cannot be truncated. This tool can only be used to cut the hard fish crackers dough.

Meanwhile crackers cutting tool by Musollini Lubis is uses the 8 (eight) fruit knifes that is driven by the hand through the stalk holders. Cutting capacity is 22 dough in 195 minutes. This tool has a lack which is the placement of the blade holder on is the less sturdy and effects of excision-cutting process less so slow [4]. Shown in Figure 6 and Figure 7.

Another with crackers cutting tool of Rice, Flour and Fish by I Made Parsa.This tool consists of a pedal (1) is rotated, then the fan blade (2) will be spinning, to cut the crackers on a parallel system of energy conversion tool (4). So crackers cut off by the rotation of the fan blade (2) material printed on mould flow crackers (4) driven by a spring (5) that is on the tip of the prints, as well as automaticallycrackers are compelled in print (4) spring (5) and then detained by anchoring pieces of cracker (3) appropriate work principles of the component parts of the engine to produce a production according to Raffei Moh. and Teja S. [5]. The results of the cutting of the crackers fell automatically holding place crackers (6). While the worktable (7) can be used to put raw crackers that are printed and cut. This tool can cut dough crackers into various forms of mold and the thin-thin pieces evenly in a fast time, where before the existence of this tool 1 circle is done within 15 minutes, with the use of this tool can be processed in 3 minutes [6]. Shown in Figure 8.

Other cutting tools is crackers cutting tool of "Kemplang" by Hasan Basri uses fishing rope. By using this tool of productivity that can be achieved of $200 \%$. These cutting will cut raw crackers "kemplang" presented "empek-empek lenjer" timely, presentable, and amply cut no attached on a rope [7]. Shown in Figure 9. The intent of the research is to make cutting tools crackers without electricity (mechanical) and the goal is to increase the amount of production.

As for crackers cutting tool by Mesin Dapur in Sidoarjo is used to cut "puli" and wheat crackers. It is composed of several pieces of $0.3 \mathrm{~mm}$ wire and the distance between each cut wire is $2 \mathrm{~mm}$. This tool use PVC pipe as anchoring guard for the distance between 


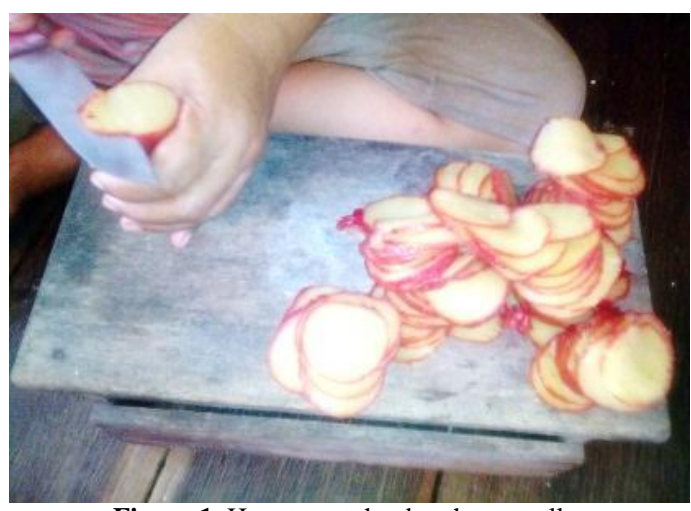

Figure 1. How to cut the dough manually.

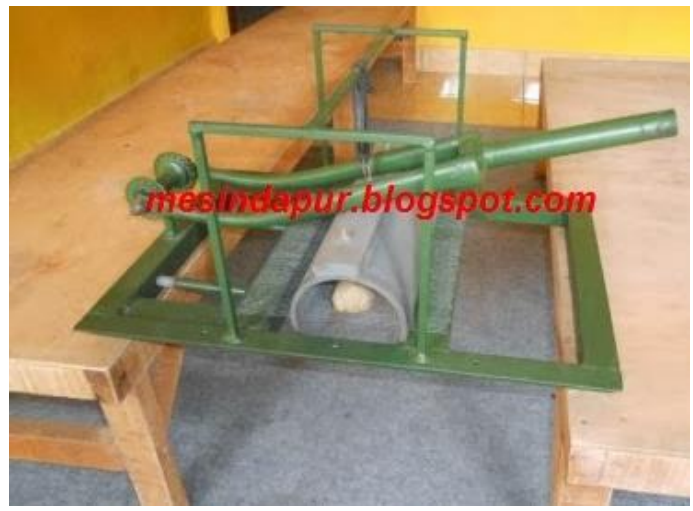

Figure 2. Mesin Dapur Crackers Cut Tool.

the wires, and the lever press is made of bicycle fork [8]. The weakness in Mesin Dapur's tools is, the process requires a strong pressure, especially on hardened dough (not more than 4 hours after boiling). So this tool operates properly on the new dough because it is still chewy. Shown in Figure 2.

This research uses the same model like crackers cutting tool by Mesin Dapur, but differ on the mechanism of the suppressor. This design was chosen because the tool is simple and without using motor movers (non-electrical). The purposes of this research is to design a tool for cutting the suitable, cheap and nonelectrical wheat crackers.

\section{METHOD}

\section{A. Tools and Materials}

The equipment used in this research is the grinding machine, welding machine, vise, pliers, screwdriver, and hacksaw. The materials used for the manufacture of cutting tools crackers are; stainless plate, stainless wire, iron elbow, bearings, pipes polyvinyl chloride (PVC), plate iron, spring-loaded, bolt and nut. As well as for materials to test is a dough of wheat crackers.

\section{B. Data Collection and Information}

Data collection through surveys and comparative study carried out in the framework of data collection through primary and secondary. Discussion with practitioners relating to research had been carried out. The survey was conducted with the aim to find and investigate the problem in cutting crackers, to determine the solutions of the problem. Then analyzing and choosing a good solution to make the design in details and doing the preliminary draft. The initial survey was carried out to the sub-districts of the City Kota Bangun

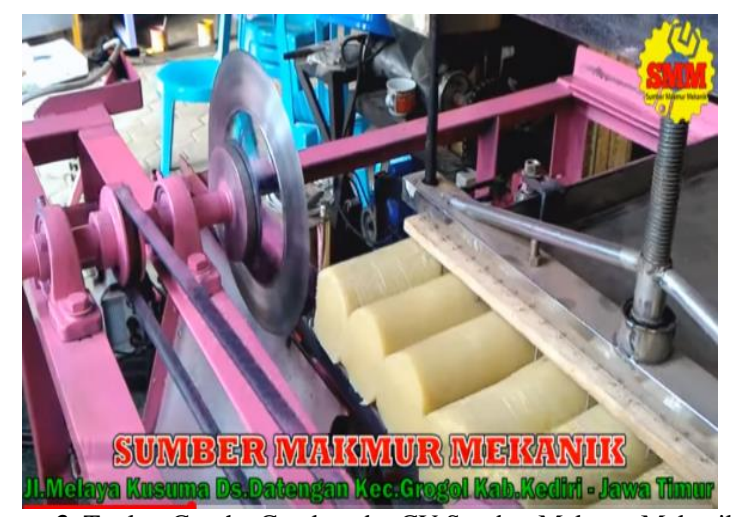

Figure 3. Tool to Cut the Crackers by CV.Sumber Makmur Mekanik.

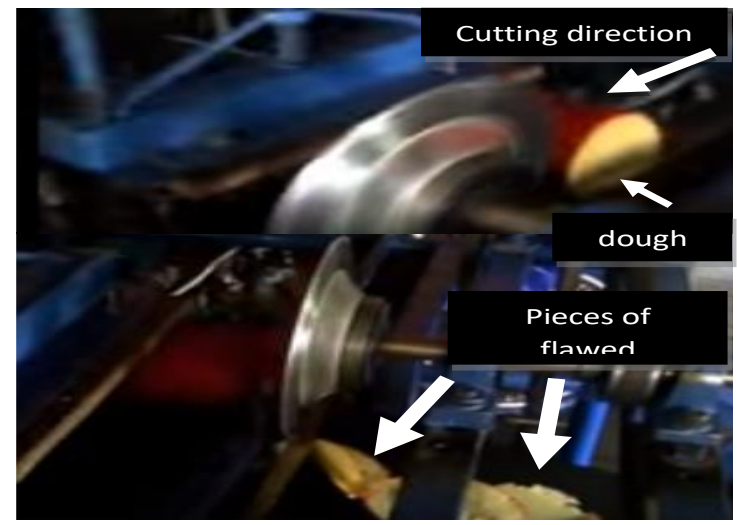

Figure 4. Tool to Cut the Crackers by Rapian Nur.

to find and investigate problems in dealing with the perpetrators of crackers industry. The site selection in this survey is in Kota Bangun because there are loads of Small Medium Enteprise crackers. The total of cracker industries today are 11 groups, each group consists of 20 participants.

\section{Work Procedures}

The theoretical framework of approach and implementation of cutting tool engineering for wheat crackers are as follows:

1) Identification of Image Work (Design tool)

According to Sirait [9] to get a good design to note form design, determine the size of the main function based on the effectiveness of an effective machine, low production cost, easy operation as well as an interesting shape and choose a suitable material. Identification of the component tool design is a step to determine the size of the cutting tools in the making the wheat crackers. Based on the identification, each component consists of 4 parts, namely, 1). Order the main buffer, 2). Part of cutters), 3). Part of suppressor, 4). Container for crackers. They can be seen in the following Figure 10 .

\section{2) Identification of Materials}

Determining the right materials is essentially a compromise between the various properties, and how to use the environment to which the properties of materials can meet the specified requirements. There are several aspects to consider in the selection of materials, namely;

a. Pay attention to the nature of the material, including: strength, hardness, elasticity, tenacity, endurance to corrosion, durability is hot, hot, moving both the nature of electricity, heavy type, the nature of magnetism, physical endurance, endurance stretch, properties are able to support, and the conductivity heat. 


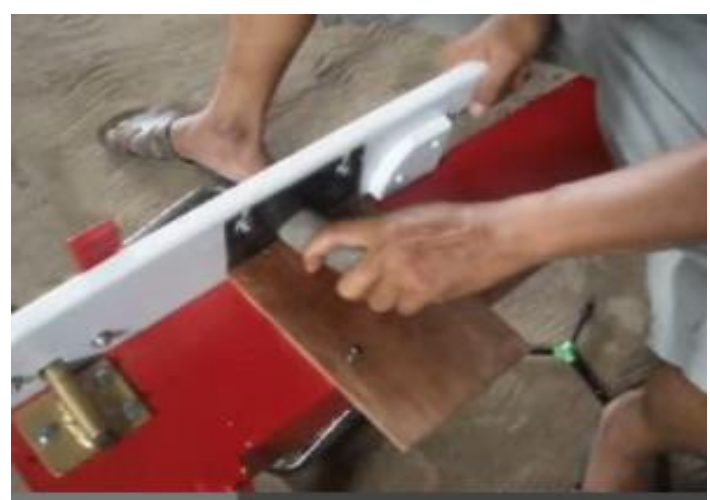

Figure 5. Tool to Cut the Crackers by Ahmad Supriyoto

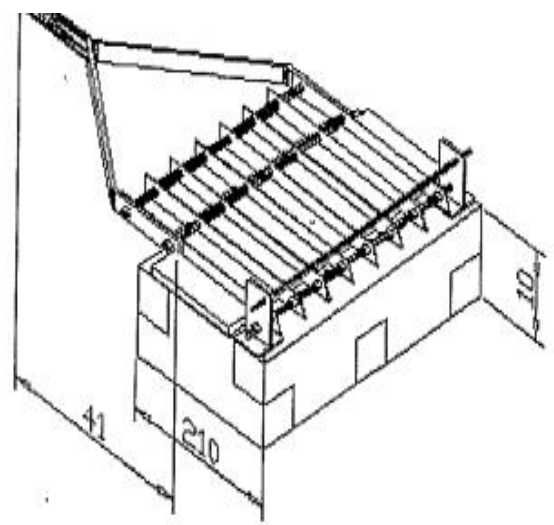

Figure 6. Design a Tool to Cut the Crackers

b. Pay attention to the economy, include: the availability of the goods, the time of the work, the cost of the work, the cost of machinery, materials and prices.

c. Pay attention to fabrication, include: being able to print, capable machine, capable of forging, capable of space, ease of connections, and heat treatment.

\section{Testing Phase}

At this stage, it conducted trials to find out whether the tool has been completed and can work as expectations. Early testing steps:

1. Insert the dough of wheat crackers on top of part of the wire cutters.

2. Pressing the part cut with rotating tools suppressor handles.

3. Is from point 2 there is a problem or not. If there is a problem, then do the repair.

4. If there is no problem (expectations), then continued with the performance to test tools.

\section{E. Performance Testing}

At this stage, do performance testing the tool to get the specification of the tool. The test measures performance of the tools:

1. Weigh the dough of wheat crackers.

2. Insert the dough of wheat crackers on top of part of the wire cutters.

3. Press the part cut by rotating tools suppressor handles.

4. Calculate the cutting process time.

5. Repeat steps 1 to 4 several times until it obtained the average time cutting crackers for a one time process.

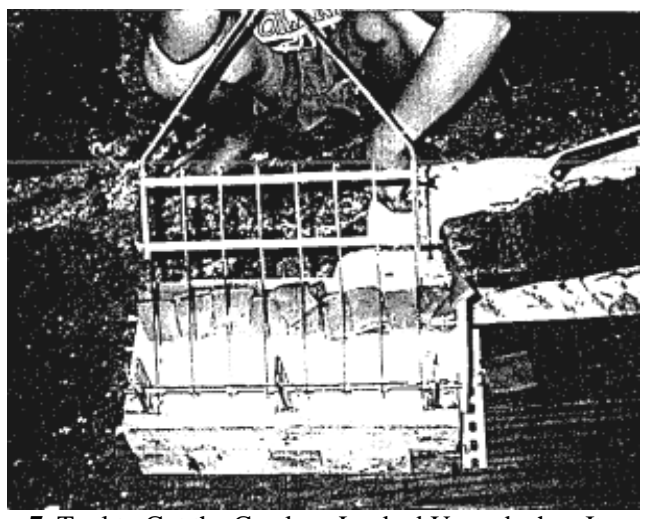

Figure 7. Tool to Cut the Crackers Looked Up and when Its use

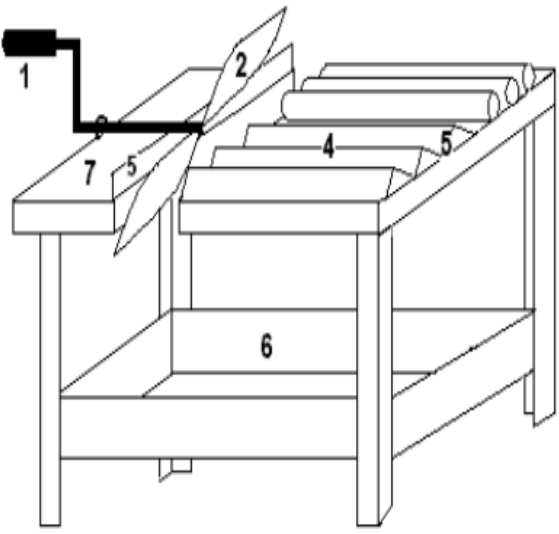

Figure 8. Tool to Cut the Crackers by I Made Parsa.

\section{RESULTS AND DISCUSSIONS}

\section{A. Results}

From the initial test results, it is obtained in mind that when it is given a dough of wheat crackers, tool is capable to cut the wheat cracker dough. Photos of testing can be seen in Figure 11.

\section{1) The Dimensions of the Cutting Tool Whole Wheat Crackers}

The dimensions of cutting tool is based on the size of the existing instruments, so that the size of the tool is no different to the existing of tool. It only changes in suppressor mechanisms and the addition of racks as well as the distance order. Cutting tool for whole wheat crackers made with the following specs; Order of the iron: high $70 \mathrm{~cm}$, length $60 \mathrm{~cm}$, width $60 \mathrm{~cm}$. stainless Shelves: length $55 \mathrm{~cm}$, width $55 \mathrm{~cm}$, thickness $2 \mathrm{~mm}$. Mechanism of suppressor of iron: length $52 \mathrm{~cm}$, width 38 $\mathrm{cm}$, height $20 \mathrm{~cm}$. Come the spring diameter $15 \mathrm{~mm} 8$.

\section{2) Performance of Testing Tools}

This testing aims to test the performance of the tool, more accurately again by doing some of the repetition of the test. The test results are shown in Figure 12. From Figure 12, there is a time difference between doing it manually and using tools to cut. Cutting manually takes average 20.10 minutes while cutting using the tool as results of engineering requires an average of 1.23 minutes.

\section{B. Discussion The Performance of Testing Tools}

The cutting tool of Fig. 5 can not be used to cut the wheat cracker dough because the wheat flour has a gluten content to produce an elastic dough [10]. 
TABLE 1.

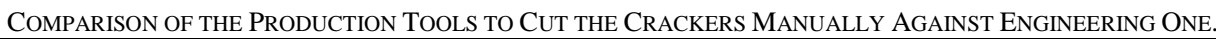

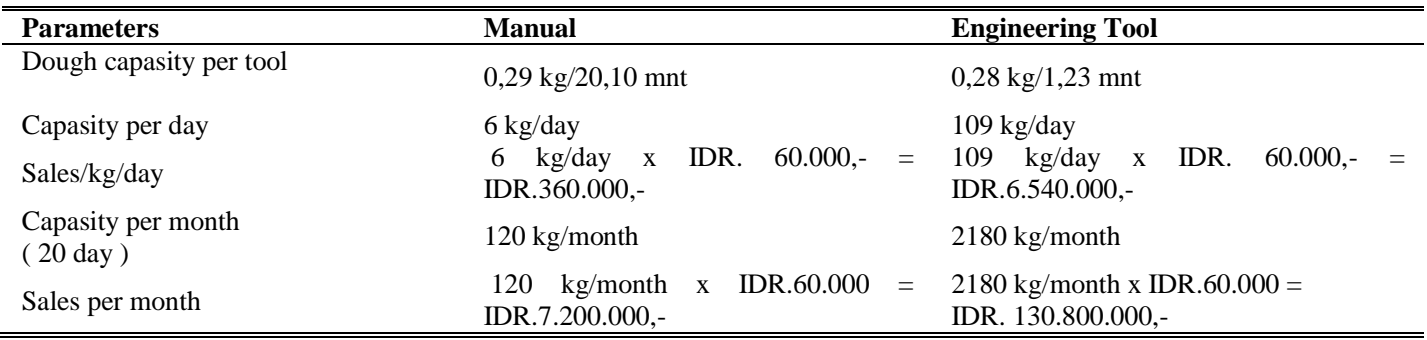

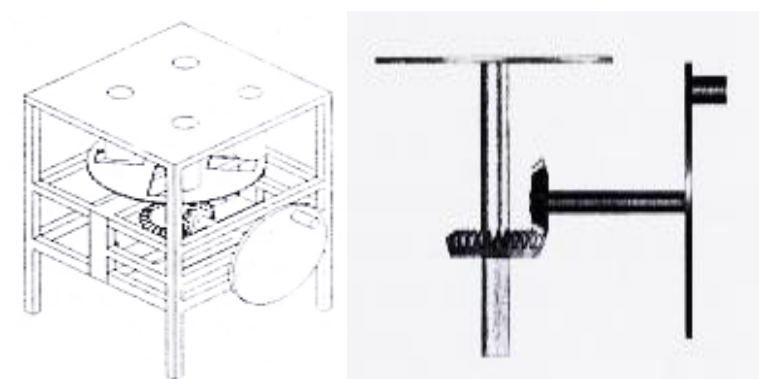

Figure 9. Tool to Cut the Crackers by Hasan Basri.
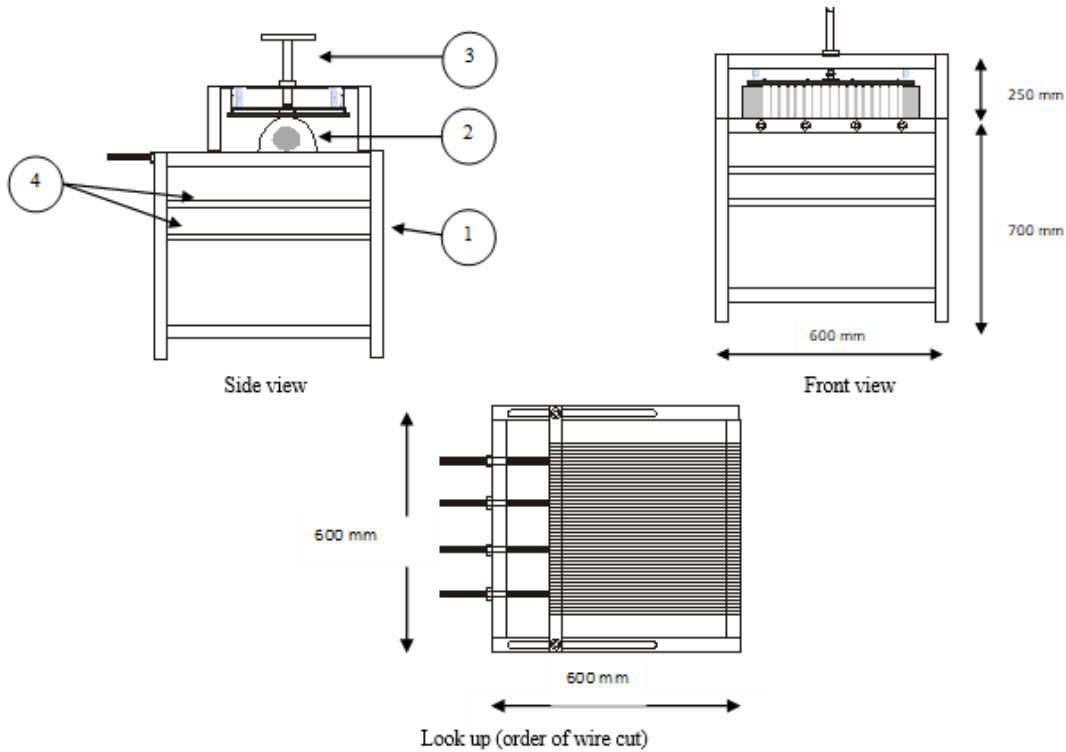

Figure 10. Design of Non-Electrical Wheat Crackers Dough Cutting Tool.

Manual cutting as in Figure 1 takes a long time and the thickness of the pieces is not the same. The hard wheat flour increased the cutting stress and surface firmness [2], so the selection of cutting using stainless wire can overcome because it only has diameter 0.35-0.4 $\mathrm{mm}$ so it can penetrate the dough quickly.

\section{1) The Technology Feasibility Aspects}

This cutting tools for wheat crackers uses a very simple technology, in terms of construction, the way to operate the tools, maintenance and non electrical. So it is very suitable for industrial scale production, small or medium enterprises.

\section{2) Aspect of Advantages Compared to Existing Technology}

As has already been mentioned, this tool has advantages compared to other tools, namely ;

a. The process of the dough blade to emphasize is using the screw system, so even the dough is hard ( 2 or 3 days), it can still be clipped properly, whereas, when we use Davit's tool, the dough should be cut maximum 4 hours after the process of boiling. This is because the pressure system relies on hand pressure only so that the nature of the hardened dough cannot be defeated only by pressing using the hand, it takes a lot of energy to cut the dough.

b. Non electrical, it is suitable for areas that do not have a steady flow of electricity.

c. Easy to operate and to maintain.

3) Economic Feasibility Aspects

Economic feasibility aspects can be seen in Table 1, i.e. by comparing this tools against manual one. The results differs in 20 working days. The calculation of the table above shows, the difference of capacity per month. There is difference $2060 \mathrm{~kg}$ or IDR. 123,600,000,-. This is an increase in the capacity of $1700 \%$.

This tool has advantages compared to other tools, the price is affordable (3-4 million IDR). Because it does not use a driving motor and electricity as well as a simple tool design. 


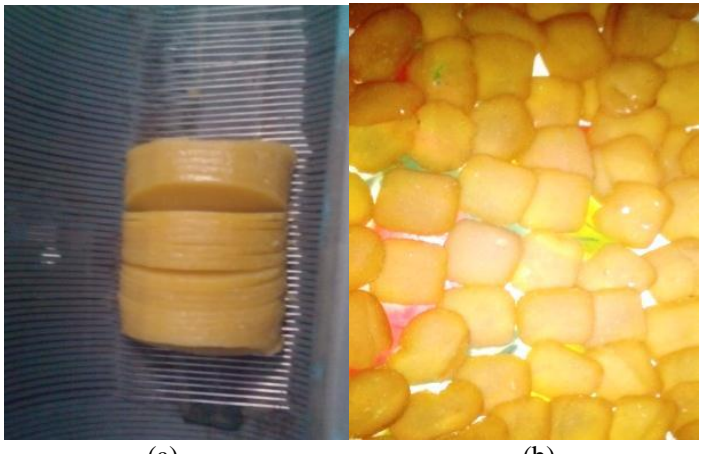

(a) (b)

Figure 11. (a) The dough when the cutting process and (b) The dough that has been truncated.

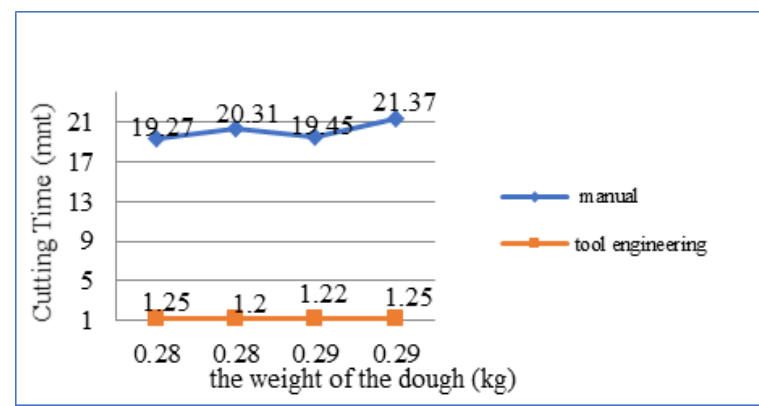

Figure 12. The test result manual and tool engineering.

\section{CONCLUSIONS}

The design of the wheat cracker cutter dough cutting tool has been made. The testing results shows that the tool works efficiently. It increases production and improves product quality. The development cost is cheap. The operation does not use electricity and easy operation and maintenance.

\section{ACKNOWLEGEMENT}

The researcher thanks the chief of Research and Standardization of Industrial Samarinda that has provided funds and SME crackers "Ananda Kiki" which has given the confidence and the chance to be researched.

\section{REFERENCES}

J. S. Sulharman and S. W. E. Wara, "Prototype Alat Pemotong Kerupuk Secara Mekanis Untuk Mengefisiensikan Waktu Pemotongan,” 2014.

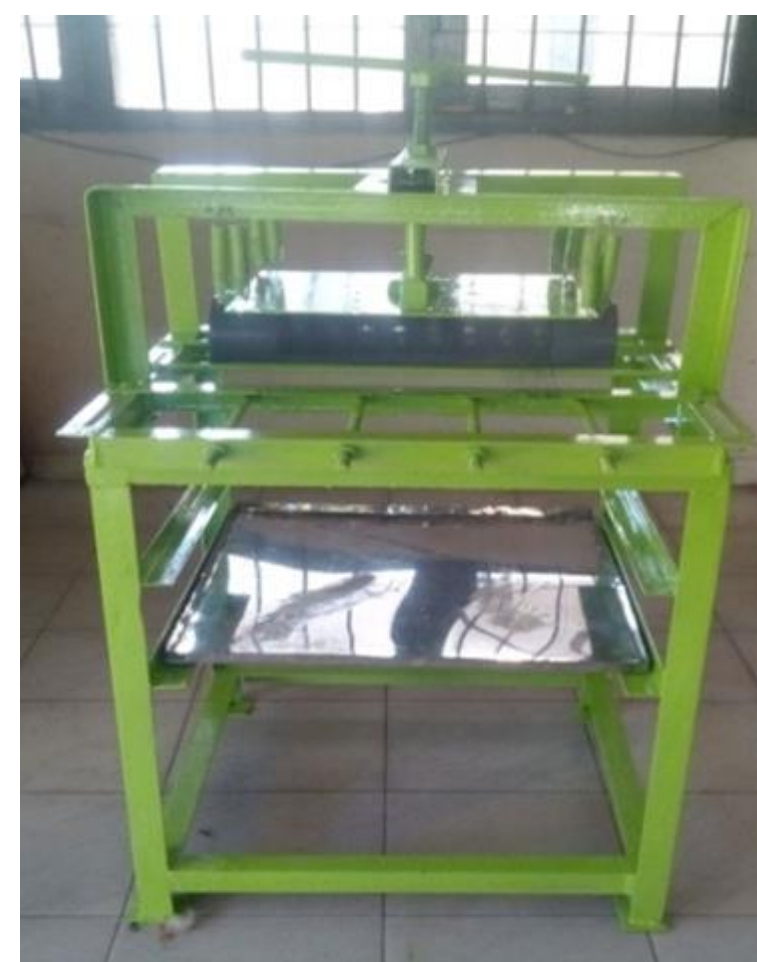

Figure 13. Wheat Crackers Dough Cutting Tool.

S. Mesin, "Mesin Pemotong Kerupuk Otomatis - Potong Krupuk Perajang Krupuk Lontong," 2016. [Online]. Available: https://www.youtube.com/watch?v=K S5A8HneyIc. [Accessed: 20-Mar-2017].

[3] R. Nur, "Mesin Pemotong Kerupuk Gandum," 2012.

[4] M. Lubis, "Desain dan Uji Performansi Alat Pemotong Adonan Kerupuk," Bogor, 1999.

[5] R. M. T. Suarpradja, "Pondasi dari Bagian-Bagian Mesin 2," 2000.

[6] I. Parsa, "Konversi Energi Pemotong Krupuk : Beras, Trigu dan Ikan Sistem Paralel Dengan Putaran Pisau Kipas," J. Ilm. Fakt. Exacta, vol. 3, no. 3, pp. 232-237, 2010.

H. Basri, I Yani, and Ismail Thamrin, "Rancang Bangun Alat Pemotong Kerupuk Kemplang untuk Meningkatkan Produktifitas dan Efisiensi Produksi," in Prosiding Seminar Nasional Teknologi dan Rekayasa Industri SNTRI 07 APPLIED TECH, 2017, pp. 1-8.

[8] M. Dapur, "Cara Kerja Mesin Pemotong Kerupuk Puli Lontongan Manual," 2013. .

[9] J. Sirait and Sulharman, "Rancang Bangun Alat Olahan Minyak Kelapa," J. Ris. Teknol. Ind., vol. 10, no. 1, pp. 7077, 2016.

[10] Florentina, "Formulasi Tepung Jagung (Zea Mays L.) Terfermentasi Dan Tepung Terigu Terhadap Sifat Kimia, Fisikokimia, Dan Sensori Mie Basah,” 2016 